\title{
Analisis Cluster Sebaran Hara Makro dan Rekomendasi Pemupukan untuk Tanaman Tebu (Saccharum officinarum Linn.)
}

\author{
Cluster Analysis of Macro Nutrient Distribution and Fertilization \\ Recommendations for Sugarcane (Saccharum officinarum Linn.)
}

Basuki, Benito Heru Purwanto, Bambang Hendro Sunarminto, Sri Nuryani Hidayah Utami

Ilmu Tanah Fakultas Pertanian UGM Yogyakarta

\begin{abstract}
The Indonesian sugar industry is under mounting pressure to minimize off-farm losses of nutrients and reduce its overall costs of production. Fertilizer inputs absorb production costs $65 \%$ of the total cost. One effort that can be done is an application of specific fertilizer recommendations based on soil analysis. This study aims to classify plot status the nitrogen total, phosphate available, kalium exchange and cluster fertilizer recommendation sugarcane (Saccharum officinarum Linn.) in Unit PG. Djatiroto, Lumajang plantation in mapping. Analysis done for 48 grids with each grid to cover 6.25 ha area. The clustering based on concentration variable of $t$ nitrogen total, phosphate available, kalium exchange, with Hierarchical Analysis cluster and Geographical Information System (GIS) methods, starting from January until May 2014. The analysis result have 5 cluster fertilizer recommendation. Those are: One cluster (Cluster 3) which consist of one grid with recommendation of $160 \mathrm{~kg} / \mathrm{ha}, 90 \mathrm{~kg} \mathrm{P}_{2} \mathrm{O}_{5} / \mathrm{ha}, 145 \mathrm{~kg} \mathrm{~K} \mathrm{O} / \mathrm{ha}$; cluster 1 which consist of 29 grids with recommendation of $160 \mathrm{~kg} / \mathrm{ha}, 135 \mathrm{~kg} \mathrm{P}_{2} \mathrm{O}_{5} / \mathrm{ha}, 175 \mathrm{~kg} \mathrm{~K} \mathrm{~K}_{2} \mathrm{O} / \mathrm{ha}$; cluster 2 which consist of 7 grids with recommendation of $120 \mathrm{~kg} / \mathrm{ha}, 90 \mathrm{~kg} \mathrm{P}_{2} \mathrm{O}_{5} / \mathrm{ha}, 175 \mathrm{~kg} \mathrm{~K} / \mathrm{O} / \mathrm{ha}$, cluster 4 which consist of 23 grids with recommendation of $160 \mathrm{~kg} / \mathrm{ha}, 135 \mathrm{~kg} \mathrm{P}_{2} \mathrm{O}_{5} / \mathrm{ha}, 175 \mathrm{~kg} \mathrm{~K} \mathrm{~K}_{2} \mathrm{O} / \mathrm{ha}$; cluster 5 which consist of 6 grids with recommendation of $120 \mathrm{~kg} / \mathrm{ha}, 135 \mathrm{~kg} \mathrm{P}_{2} \mathrm{O}_{5} / \mathrm{ha}, 175 \mathrm{~kg} \mathrm{~K} \mathrm{~K}_{2} \mathrm{O} / \mathrm{ha}$.
\end{abstract}

Keywords: Cluster Analysis, Nutrient Status, Sugarcane, Fertilizer Recommendation

\section{INTISARI}

Industri gula Indonesia berada di bawah tekanan untuk meminimalkan kehilangan nutrisi off-farm dan mengurangi seluruh biaya produksi. Saprodi pupuk menyerap biaya produksi $65 \%$ dari total biaya. Salah satu upaya yang dapat dilakukan adalah penerapan rekomendasi pupuk spesifik berdasarkan analisis tanah. Penelitian ini bertujuan untuk mengelompokkan petak Status Hara N Total, P-Tersedia, K-Tertukar dan cluster rekomendasi pemupukan tanaman tebu (Saccharum officinarum Linn.) di kebun Unit Usaha PG. Djatiroto, Lumajang melalui pemetaan. Analisis dilakukan terhadap 48 sampel, dengan 1 sampel mewakili petak 6,25 ha. Pengelompokan petak berdasarkan peubah konsentrasi N Total, P-Tersedia, K-Tertukar dilakukan dengan metode Hierarchical cluster Analysis dan Sistem Informasi Geografis (GIS) mulai dari bulan Januari sampai Mei 2014. Hasil analisis mendapatkan 5 kelompok area rekomendasi pemupukan. Satu

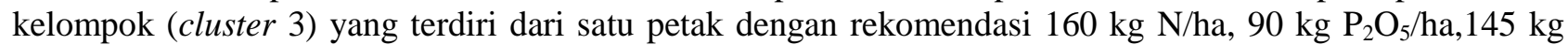
$\mathrm{K}_{2} \mathrm{O} / \mathrm{ha}$; cluster 1 yang terdiri dari 29 petak dengan rekomendasi $160 \mathrm{~kg} \mathrm{~N} / \mathrm{ha}, 90 \mathrm{~kg} \mathrm{P}_{2} \mathrm{O}_{5} / \mathrm{ha}, 175 \mathrm{~kg}$ $\mathrm{K}_{2} \mathrm{O} / \mathrm{ha}$; cluster 2 yang terdiri dari 7 petak dengan rekomendasi $120 \mathrm{~kg} \mathrm{~N} / \mathrm{ha}, 90 \mathrm{~kg} \mathrm{P}_{2} \mathrm{O}_{5} / \mathrm{ha}, 175 \mathrm{~kg} \mathrm{~K}{ }_{2} \mathrm{O} / \mathrm{ha}$, cluster 4 yang terdiri dari 23 petak dengan rekomendasi $160 \mathrm{~kg} \mathrm{~N} / \mathrm{ha}, 135 \mathrm{~kg} \mathrm{P}_{2} \mathrm{O}_{5} / \mathrm{ha}, 175 \mathrm{~kg} \mathrm{~K}{ }_{2} \mathrm{O} / \mathrm{ha}$; cluster 5 yang terdiri dari 6 petak dengan rekomendasi $120 \mathrm{~kg} \mathrm{~N} / \mathrm{ha}, 135 \mathrm{~kg} \mathrm{P}_{2} \mathrm{O}_{5} / \mathrm{ha}, 175 \mathrm{~kg} \mathrm{~K} \mathrm{O} / \mathrm{ha}$.

Kata kunci: Analisis Cluster, Status Hara, Tebu, Rekomendasi Pemupukan

\section{PENDAHULUAN}

Tebu (Saccharum officinarum Linn.) merupakan tanaman perkebunan/industri yang memiliki peran penting, karena di dalam batangnya terkandung cairan gula. Sekitar $65 \%$ produksi gula di dunia berasal dari tebu. Banyaknya produk yang memanfaatkan gula 
sebagai bahan baku dalam industri, mengakibatkan permintaan akan komoditas tebu juga terus meningkat. Indonesia pada masa lalu, dikenal sebagai produsen gula sekaligus eksportir gula terbesar. Produksi gula nasional Indonesia pada saat ini, mengalami kemerosotan sangat tajam. Kemerosotan ini menjadikan Indonesia, yang pernah menjadi produsen gula sekaligus eksportir gula, berubah menjadi importer gula terbesar (Bakti, 2009).

Kehilangan potensi ekonomi yang sebenarnya diterima pelaku bisnis gula di Indonesia, baik petani maupun pengusaha gula, menjadi sangat besar. Kemerosotan produksi tebu di Indonesia, disebabkan diantaranya karena kebijakan pertanian yang kurang mendukung, pemakaian pupuk yang tidak rasional sehingga tidak efisien.

Produktivitas gula di unit usaha Pabrik Gula (PG) Djatiroto Lumajang mengalami pasang surut, seiring dengan perubahan lingkungan yang terjadi dan pelaksanaan budidaya. Faktor nutrisi tanaman merupakan salah satu kendala dalam budidaya tebu. Oleh karena itu pemahaman tentang jumlah nutrisi yang diberikan ke tanaman lewat tanah dalam bentuk pemupukan sangat penting. Faktor pemupukan selama kurun tujuh tahun terakhir ini kurang dipandang sebagai salah satu penunjang peningkatan produktivitas dan efisiensi. Data produktifitas unit usaha PG. Djatiroto menunjukkan, bahwa Masa Tanam (MT) tahun 2006/2007 sampai (MT) tahun 2012/2013 terjadi penurunan produksi tebu per hektar sekitar 15,96-42,27\% dari potensi lahan sebenarnya, begitu pula pada jumlah hablur per hektar menurun 10,71-18,28\%(Puslit Sukosari, 2014). Sistem tanam monokultur terus-menerus mampu mengurangi hara tersedia dalam tanah, bila didukung dengan penambahan unsur hara dalam tanah tidak sesuai dan tidak rasional (Hunsigi, 2001). Kebijakan pemupukan yang tidak sesuai akan berpengaruh terhadap produktifitas dan nilai ekonomi.

Dalam sistem perkebunan tebu, pemupukan menjadi faktor yang sangat strategis, karena merupakan sarana produksi yang menyerap biaya budidaya paling tinggi $65 \%$ dari total biaya bila dibandingkan sarana produksi yang lain. Untuk mengefisiensi sarana produksi melalui efisiensi pupuk yang diberikan dan spesifik lokasi, perlu mengetahui peta sebaran status hara tanah terutama hara makro $(\mathrm{N}, \mathrm{P}$, maupun $\mathrm{K})$ di areal pertanaman tebu. Peta sebaran status hara tanah sebagai dasar dalam menentukan takaran dan rekomendasi jumlah pupuk yang diberikan yang bersifat spesifik lokasi (specific location) dan mempunyai nilai ekonomi.

\section{BAHAN DAN METODE}

\section{Bahan dan Peralatan}

Bahan yang digunakan dalam penelitian ini adalah data primer meliputi: sampel tanah dan khemikalia untuk analisis laboratorium yang meliputi Nitrogen (N) total; Fosfat $\left(\mathrm{P}_{2} \mathrm{O}_{5}\right)$ tersedia; Kalium $\left(\mathrm{K}_{2} \mathrm{O}\right)$ tersedia; $\mathrm{pH}$; C-Organik, data sekunder yang meliputi: peta tanah skala 1:10.000; peta Geologi skala 1:100.000; data anasir iklim (curah hujan, suhu, lama penyinaran matahari, kelembaban udara, dan kecepatan angin). Peralatan yang digunakan dalam penelitian ini meliputi Global Positioning System (GPS), Perangkat lunak software Minitab versi 16, dan ArcGis 10. serta perangkat keras komputer dan peralatan pendukung survai lapang dan analisis sifat kimia tanah.

\section{Metode}

Dalam pelaksanaan penelitian ini dilakukan beberapa tahapan. Adapun tata laksana kegiatan yang dilaksanakan dalam penelitian ini adalah sebagai berikut: 1) Tahap persiapan: meliputi pengumpulan data awal, yaitu data iklim, data tanah (satuan peta tanah). Setiap satuan peta tanah ditentukan titik sampel yang akan dicuplik, dengan titik sampel mewakili luasan 6,25 ha. Penentuan sampling menggunakan metode grid. Jumlah titik sampel berjumlah 48 sampel dalam total luasan 269,28 ha (Gambar 1). Tiap sampel tanah yang dicuplik berupa komposit dari 8-10 titik bor yang dianggap mempunyai kesamaan sifat, 2) Tahap survey lapangan; meliputi pengambilan sampel tanah dengan alat yang sudah dipersiapkan dan sampel tanah dibawa ke laboratorium untuk dianalisis, 3) Tahap analisis laboratorium; meliputi analisis $\mathrm{pH} \mathrm{H}_{2} \mathrm{O}$ (metode suspensi 1:2,5); C-Organik (metode WalkeyBlack/tetrimetri); N-total (metode Kjeldahl/tetrimetri); P-tersedia $\left(\mathrm{P}_{2} \mathrm{O}_{5}\right)$ (metode Olsen); K-tersedia $\left(\mathrm{K}_{2} \mathrm{O}\right)$ (metode Ekstrak $\mathrm{NH}_{4} \mathrm{OAc} 1 \mathrm{M}, \mathrm{pH}$ 7) (Balittan, 2009), 4) Tabulasi dan analisis data; data yang diperoleh dikelompokkan berdasarkan kriteria pengharkatan sifat-sifat tanah untuk budidaya tebu yang dibuat oleh Balai Penelitian dan Pengembangan Gula Indonesia (P3GI) Pasuruan (Pawirosemadi, 2011) (Tabel 1), Kemudian terhadap data hasil dilakukan analisis gerombol atau cluster dengan paket program statistik MINITAB. 
Pengelompokan petak berdasarkan peubah konsentrasi N- total; P-tersedia $\left(\mathrm{P}_{2} \mathrm{O}_{5}\right)$; K-tersedia $\left(\mathrm{K}_{2} \mathrm{O}\right)$ dilakukan dengan metode Hierarchical cluster Analysis. Sebagai ukuran kemiripan digunakan konsep jarak Euclid. Penentuan banyaknya kelompok yang bermakna dilakukan dengan memotong dendogram pada selisih jarak penggabungan terbesar. Kemudianmendeskripsikan karakteristik masingmasing kelompok serta melihat perbedaan yang ada antar kelompok yang terbentuk, 5) Rekomendasi pemupukan; meliputi hasil analisis cluster dipadukan (maching) dengan jumlah pupuk yang harus diberikan sesuai yang dibuat oleh Balai Penelitian dan Pengembangan Gula Indonesia (P3GI) Pasuruan (Pawirosemadi, 2011) (Tabel 2.). Dengan menggunakan limitasi sederhana, selanjutnya dibuat peta wilayah rekomendasi dengan menggunakan bantuan komputer dan software pemetaan ArcGis versi 10.

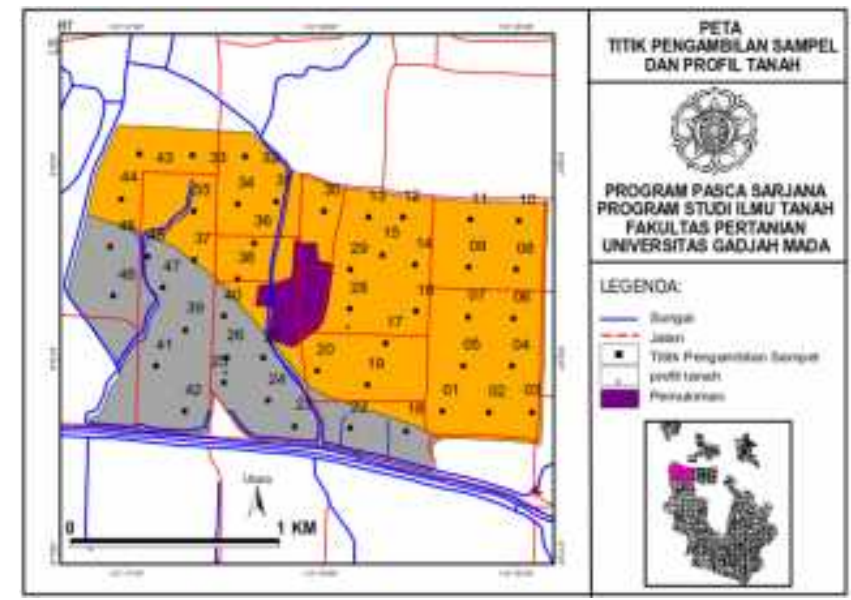

Gambar 1. Peta Titik Pengambilan Sampel da Profil Tanah

Tabel 1. Klasifikasi Status/Jenjang Ideal pH, Bahan Organik, dan Hara Makro N, P, K Tanah Bagi Tanaman Tebu

\begin{tabular}{ccccc}
\hline \multirow{2}{*}{ Parameter tanah } & \multirow{2}{*}{ Satuan } & Rendah & Status & Sedang \\
\cline { 3 - 5 } & $\%$ & $<2$ & $2-50$ & Tinggi \\
\hline Bahan Organik & $\%$ & $<0.10$ & $0.10-0.13$ & $>5$ \\
N Total & $\mathrm{mg} / \mathrm{g}$ & $<30$ & $30-50$ & $>0.13$ \\
P-tersedia $\left(\mathrm{P}_{2} \mathrm{O}_{5}\right)$ & $\mathrm{mg} / \mathrm{g}$ & $<100$ & $100-500$ & $>50$ \\
K-tersedia $\left(\mathrm{K}_{2} \mathrm{O}\right)$ & & $<5.5$ & $5.5-7.5$ & $>7.5$ \\
pH Tanah & & &
\end{tabular}

Tabel 2. Takaran Pupuk N, P, K Untuk Wilayah Penelitian

\begin{tabular}{cccc}
\hline \multirow{2}{*}{ Status/Jenjang } & \multicolumn{3}{c}{ Takaran Pupuk yang diberikan } \\
\cline { 2 - 4 } & $\mathrm{Kg} \mathrm{N} / \mathrm{ha}$ & $\mathrm{Kg} \mathrm{P}_{2} \mathrm{O}_{5} /$ ha & $\mathrm{Kg} \mathrm{K}_{2} \mathrm{O} / \mathrm{ha}$ \\
\hline Tinggi & 90 & 90 & 95 \\
Sedang & 120 & 135 & 145 \\
Rendah & 160 & 180 & 175 \\
\hline
\end{tabular}

\section{HASIL DAN PEMBAHASAN}

\section{Kondisi Geografis}

Pabrik gula Djatiroto, secara administrative termasuk ke dalam wilayah Kecamatan Djatiroto, Kabupaten Lumajang, Propinsi Jawa Timur. Lokasi survey secara geografis terletak pada $113^{\circ}$ 17 '20"' $113^{\circ} 18$ '50' Bujur Timur dan $8^{\circ} 5$ ' 45 ', $8^{\mathrm{O}}$ 6'47" Lintang Selatan serta berada pada ketinggian 30-50 meter diatas permukaan laut.
Daerah penelitian, disusun secara geologi oleh batuan-batuan dari Batuan Gunungapi Lamongan, dan Aluvium. Formasi geologi yang terbentuk karena aktivitas gunung berapi yaitu formasi Batuan Gunung Api Lamongan (Qvl) bersusunan breksi gunungapi, tuff dan lava basalt di bagian timur laut. Endapan aluvium terdiri atas kerakal, kerikil, pasir dan lumpur merupakan bahan rombakan dari formasi-formasi yang lebih tua serta hasil rombakan produk letusan G. Mahameru 
(Herman, 2006). Dari hasil analisis berdasarkan analisis iklim Oldeman terhadap parameter iklim data curah hujan bulanan wilayah penelitian PG. Djatioro dapat digolongkan berdasarkan tipe iklim C2 (Bulan Basah 5-6 bulan dan bulan kering 2-3 bulan). Suhu udara bulanan rata-rata berkisar antara $25,8-28,4^{\circ}$ C. Kelembaban udara berkisar antara 65,9 - 72,3\%. Kecepatan angin menunjukkan angka yang relatif rendah yaitu antara $0,8-1,2 \mathrm{~km} / \mathrm{jam}$.

\section{Kemasaman, Bahan Organik Dan Sebaran Hara Makro N, P, Dan K Tanah}

\section{Kemasaman Tanah}

Dari hasil uji $\mathrm{pH}$ laboratoriaum menunjukkan bahwa derajad kemasaman $(\mathrm{pH})$ tanah di daerah penelitian rata-rata 5,86 dengan sebaran variasi yang beragam. Derajad kemasaman tersebut terdiri dari 2 status kategori yaitu rendah dan sedang yang disajikan di dalam Tabel 3. Tebu memang masih dapat hidup dengan normal pada kisaran $\mathrm{pH}$ tanah yang lebar, yaitu antara 4,5-8,5, namun pertumbuhan dan menghasilkan dengan baik dan optimal pada kisaran $\mathrm{pH}$ tanah antara 5,5-7,5(Hunsigi, 2001, Pawirosemadi, 2011).

\section{Bahan Organik}

Kadar bahan organik (BO) tanah d di daerah penelitian rata-rata $2,02 \%$ dengan sebaran yang variasi yaitu kategori rendah sampai sedang. Hanya sebagian kecil wilayah yang memiliki kadar bahan organik tinggi sebagaimana disajikan pada Tabel 4.

Di wilayah penelitian dengan luas 3,67 ha atau sebesar $1,7 \%$ dari luas total, yang status kadar Bahan Organik tanahnya tinggi. Sisa luasan yang lain, dengan luasan 123 ha atau sebesar 45,68\% dari luas total, status kadar bahan organik tanahnya sedang, dan sebagian yang lain dengan luas 142,61 ha atau sebesar 52,96\% dari luas total, status kadar bahan organik tanahnya rendah.

Tabel 3. Sebaran $\mathrm{pH}$ Tanah

\begin{tabular}{ccc}
\hline Status pH & Luas (ha) & $\%$ \\
\hline $\begin{array}{c}\text { Sedang }(5-5- \\
7,5)\end{array}$ & 224,18 & 83,25 \\
Tinggi $(<5,5)$ & 45,10 & 16,75 \\
\hline Jumlah Total & 269,28 & 100,00 \\
\hline
\end{tabular}

Sumber: Hasil Analisis Laboratorium

Tabel 4. Sebaran Bahan Organik Tanah

\begin{tabular}{ccc}
\hline $\begin{array}{c}\text { Status Bahan } \\
\text { Organik }\end{array}$ & Luas (ha) & $\%$ \\
\hline Tinggi $(>5 \%)$ & 3,67 & 1,36 \\
Sedang $(2-5 \%)$ & 123,00 & 45,68 \\
Rendah $(<2 \%)$ & 142,61 & 52,96 \\
\hline Jumlah Total & 269,28 & 100,00
\end{tabular}

Sumber: Hasil Analisis Laboratorium

\section{Nitrogen}

Sebagian besar wilayah lahan penelitian di unit usaha PG. Djatiroto memiliki kadar nitrogen (N) tanah rendah dan hanya sebagian kecil areal yang memiliki kadar $\mathrm{N}$ Tanah sedang-tinggi. Di wilayah penelitian ada sedikit petak kebun dengan luas 32,51 ha atau sebesar $12,07 \%$ dari luas total, yang status kadar $\mathrm{N}$ tanahnya tinggi.

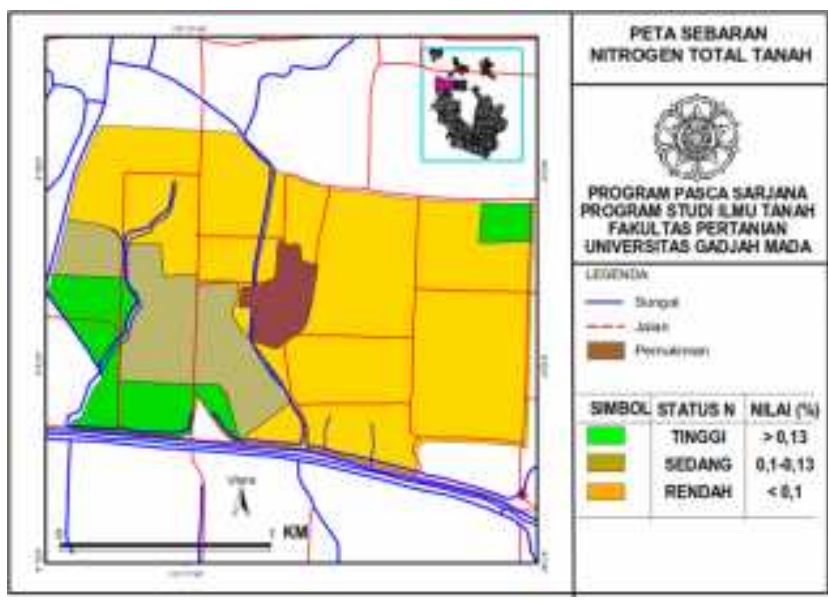

Gambar 2. Peta Sebaran Nitrogen Tanah 
Sebagian besar kebun dengan luas 192,39 ha atau sebesar $71,45 \%$ dari luas total, status kadar $\mathrm{N}$ tanahnya rendah, dan sebagian yang lain dengan luas 44,38 ha atau sebesar $16,48 \%$ dari luas total, status kadar $\mathrm{N}$ tanahnya sedang. Adapun gambar yang menunjukkan sebaran Nitrogen Total Tanah dilokasi penelitian dapat dilihat pada Gambar 2.

\section{Fosfat Tersedia}

Fosfor tersedia adalah unsur fosfat yang terdapat di dalam tanah dalam bentuk tersedia bagi tanaman serta dapat dimanfaatkan oleh tanaman untuk proses metabolisme. Dari hasil analisis contoh tanah, kandungan unsur P-tersedia yang terendah pada sampel ke-24, sebesar 30 $\mathrm{mg} / \mathrm{g}$ dan yang tertinggi pada sampel tanah ke-13, sebesar $300 \mathrm{mg} / \mathrm{g}$.

Berdasarkan kriteria penilaian sifat tanah untuk budidaya tanaman tebu Balai Penelitian dan Pengembangan Gula Indonesia (1996) maka lokasi penelitian dapat digolongkan menjadi 2 golongan status hara yakni sedang, dan tinggi. Luas wilayah dengan status hara P-tersedia sedang 26,61 Ha atau 9,88\%, dan status hara Ptersedia tinggi $242,67 \mathrm{Ha}$ atau $90,12 \%$ dari total areal wilayah penelitian (Gambar 3).

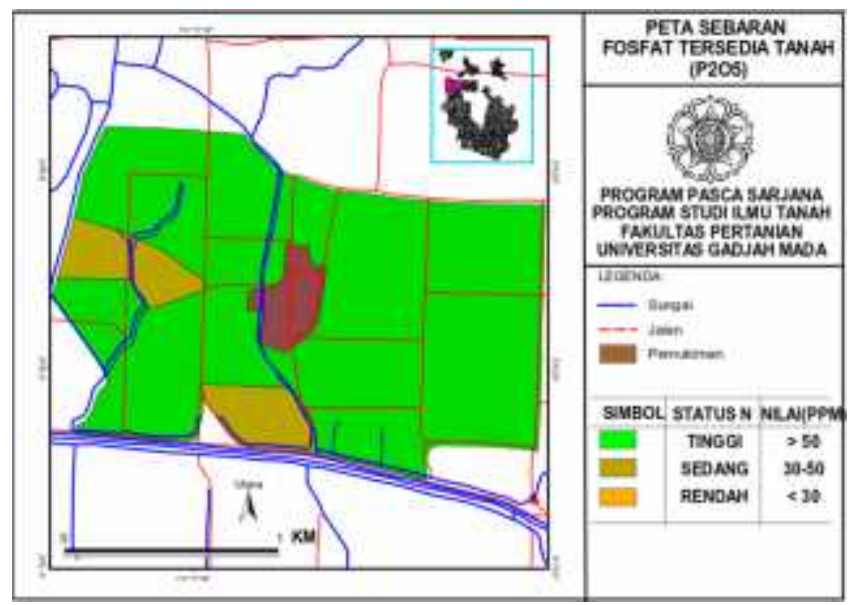

Gambar 3. Peta Sebaran Fosfat Tersedia Tanah $\left(\mathrm{P}_{2} \mathrm{O}_{5}\right)$

Menurut status hara P-tersedia pada Gambar 4 , maka status tinggi lebih dominan atau memiliki luasan yang lebih besar daripada status sedang, berarti tanah pada lokasi penelitian tergolong memiliki kandungan P-tersedia yang tinggi dan berpotensi tinggi dalam menyediakan unsur fosfat untuk kebutuhan tanaman yang dihubungkan dengan jenis tanah Alfisol dan Inceptisol yang terdapat pada lokasi penelitian maka hal ini sesuai dengan pernyataan Sanchez (1992) bahwa tanah yang mengalami perkembangan biasanya memiliki daya tambah fosfat yang tinggi. Faktor lain dari kadar $\mathrm{P}$ tanah yang relatif tinggi dapat terjadi diduga karena ada tumpukan sisa pupuk $\mathrm{P}$ di dalam tanah (berasal dari pupuk yang diberikan kepada tanaman-tanaman sebelumnya), secara umum tanaman hanya dapat menyerap P kurang lebih 25\% dari jumlah $\mathrm{P}$ yang diberikan berupa pupuk (Ismail, 2005).

\section{Kalium Tersedia}

Menurut hasil analisis kimia dari sampel tanah untuk unsur K-tersedia, maka dapat ditentukan bahwa nilai K-tersedia tanah $(\mathrm{mg} / \mathrm{g})$ yang paling rendah terdapat pada sampel ke-25 sebesar $10,03 \mathrm{mg} / \mathrm{g}$ dan yang paling tinggi terdapat pada sampel ke-5 sebesar 126,92 mg/g. Berdasarkan kriteria penilaian sifat tanah untuk budidaya tanaman tebu Balai Penelitian dan Pengembangan Gula Indonesia (1996) maka lokasi penelitian dapat digolongkan menjadi 2 golongan status hara yakni rendah, dan sedang.

Luas wilayah dengan status hara K-tersedia sedang $31,31 \mathrm{Ha}$ atau $11,63 \%$, dan status hara Ptersedia rendah $237,97 \mathrm{Ha}$ atau $88,37 \%$ dari total areal wilayah penelitian. Berikut ini disajikan peta status hara K-tersedia yang membagi wilayah menjadi 2 bagian dengan luasnya masing-masing (Gambar 4). Jika diamati dari peta di atas, dapat disimpulkan bahwa kandungan (jumlah) unsur kalium yang dapat dipertukarkan/ tersedia secara umum pada wilayah tersebut adalah rendah.

Rendahnya nilai $\mathrm{K}$ tersedia pada wilayah ini dikarenakan oleh beberapa faktor antara lain pengambilan unsur kalium oleh tanaman, pencucian oleh air, dan erosi. Maka untuk mengatasi masalah Hakim et al., (1986) menyatakan dengan pemberian asam karbonat dimana kalium yang dibebaskan dapat diabsorbsi 
tanaman, hilang bersama air draenase atau diabsorbsi oleh koloid lempung (clay).

\section{Pengelompokan (Cluster) Data}

Dari seluruh hasil analisis dan peta status hara di atas, dilakukan penggabungan (overlay) antara status hara $\mathrm{N}$ total, P-tersedia, dan K-tersedia dengan analisis cluster.

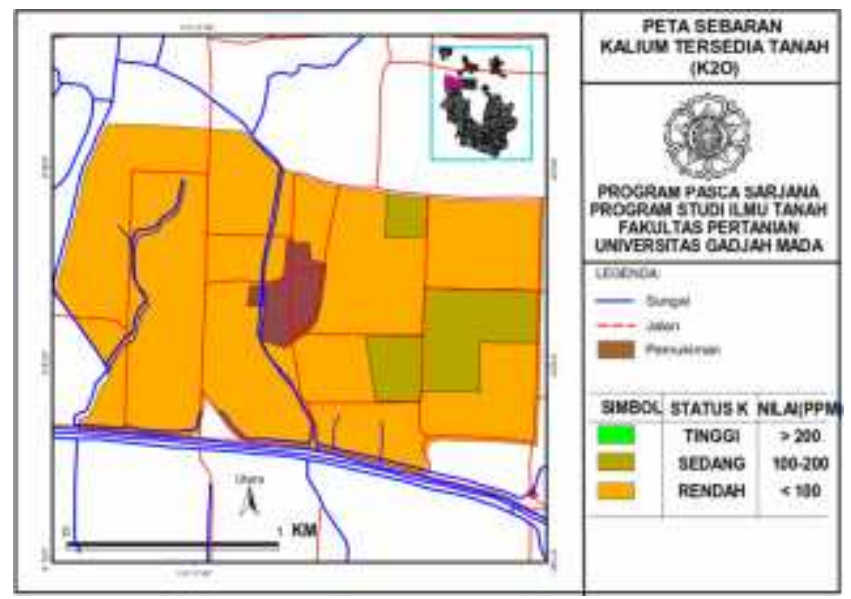

Gambar 4. Peta Sebaran Kalium Tersedia Tanah $\left(\mathrm{K}_{2} \mathrm{O}\right)$

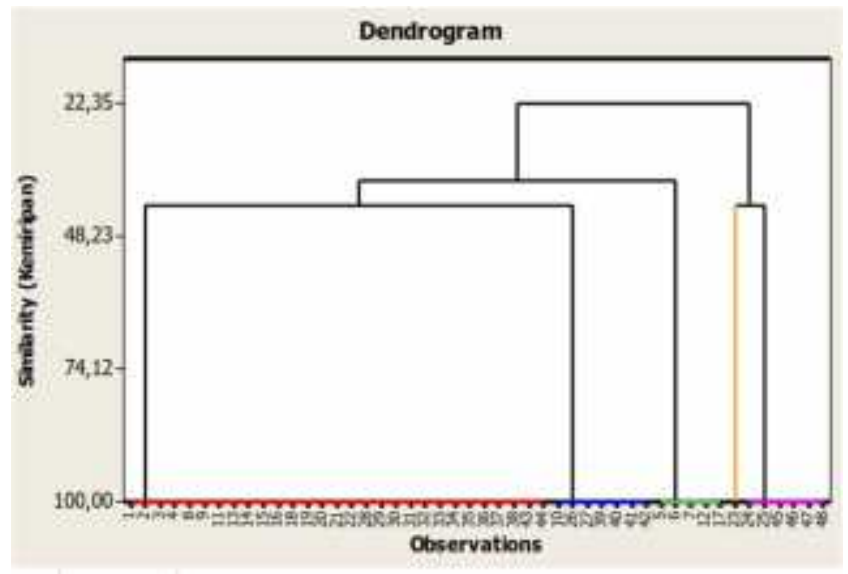

Gambar 5. Dendrogram

Hasil analisis cluster berupa dendogram pengelompokkan sesuai Gambar 5. Hasil analisis cluster dengan jumlah kelompok atau cluster yang paling bisa mewakili kelompok dengan klasifikasi yang jelas, menghasilkan 5cluster/pengelompokan titik pengambilan sampel yaitu:

1. Kelompok I : Termasuk 29 titip pengambilan sampel/nomor sampel, meliputi nomor sampel $1,2,3,4,8,9,11,13,14,15,16,18,19,20$, $21,22,28,29,30,31,32,33,34,35,36,37$, 38 , 43, dan 44; dengan pengelompokan konsentrasi Nitrogen total di dalam tanah dalam kategori rendah $(<0,10 \%)$, Fosfattersedia $\left(\mathrm{P}_{2} \mathrm{O}_{5} \mathrm{mg} / \mathrm{g}\right)$ di dalam tanah dalam kategori tinggi $(>50 \mathrm{mg} / \mathrm{g})$, dan Kaliumtersedia $\left(\mathrm{K}_{2} \mathrm{O} \mathrm{mg} / \mathrm{g}\right)$ di dalam tanah dalam kategori rendah $(<100 \mathrm{mg} / \mathrm{g})$.
2. Kelompok II : Termasuk 7 titip pengambilan sampel/nomor sampel, meliputi nomor sampel $10,26,27,39,40,41$, dan 42; dengan pengelompokan konsentrasi Nitrogen total di dalam tanah dalam kategori sedang $(0,10$ $0,13 \%)$, Fosfat-tersedia $\left(\mathrm{P}_{2} \mathrm{O}_{5} \mathrm{mg} / \mathrm{g}\right)$ di dalam tanah dalam kategori tinggi (>50 mg/g), dan Kalium-tersedia $\left(\mathrm{K}_{2} \mathrm{O} \mathrm{mg} / \mathrm{g}\right)$ di dalam tanah dalam kategori rendah $(<100 \mathrm{mg} / \mathrm{g})$.

3. Kelompok III : Termasuk 5 titip pengambilan sampel/nomor sampel, meliputi nomor sampel $5,6,7,12$, dan 17; dengan pengelompokan konsentrasi Nitrogen total di dalam tanah dalam kategori rendah $(<0,10 \%)$, Fosfattersedia $\left(\mathrm{P}_{2} \mathrm{O}_{5} \mathrm{mg} / \mathrm{g}\right)$ di dalam tanah dalam kategori tinggi $(>50 \mathrm{mg} / \mathrm{g})$, dan Kaliumtersedia $\left(\mathrm{K}_{2} \mathrm{O} \mathrm{mg} / \mathrm{g}\right)$ di dalam tanah dalam kategori sedang $(100-200 \mathrm{mg} / \mathrm{g})$. 
4. Kelompok IV : Termasuk 1 titik pengambilan sampel/nomor sampel, meliputi nomor sampel 23; dengan pengelompokan konsentrasi Nitrogen total di dalam tanah dalam kategori rendah $(<0,10 \%)$, Fosfat-tersedia $\left(\mathrm{P}_{2} \mathrm{O}_{5} \mathrm{mg} / \mathrm{g}\right)$ di dalam tanah dalam kategori Sedang (30-50 $\mathrm{mg} / \mathrm{g})$, dan Kalium-tersedia $\left(\mathrm{K}_{2} \mathrm{O} \mathrm{mg} / \mathrm{g}\right)$ di dalam tanah dalam kategori rendah $\quad<100$ $\mathrm{mg} / \mathrm{g}$ ).
5. Kelompok V : Termasuk 6 titip pengambilan sampel/nomor sampel, meliputi nomor sampel $24,25,45,46,47$, dan 48; dengan pengelompokan konsentrasi Nitrogen total di dalam tanah dalam kategori sedang $(0,10-$ $0,13 \%)$, Fosfat-tersedia $\left(\mathrm{P}_{2} \mathrm{O}_{5} \mathrm{mg} / \mathrm{g}\right)$ di dalam tanah dalam kategori Sedang $(30-50 \mathrm{mg} / \mathrm{g})$, dan Kalium-tersedia $\left(\mathrm{K}_{2} \mathrm{O} \mathrm{mg} / \mathrm{g}\right)$ di dalam tanah dalam kategori rendah $(<100 \mathrm{mg} / \mathrm{g})$.

Tabel 5. Karakteristik Kelompok (Cluster) Titik Pengambilan Sampel Wilayah Pemetaan Konsentrasi Unsur Hara

\begin{tabular}{cccc}
\hline Kelompok (Cluster) & Nitrogen $(\%)$ & Fosfat-tersedia $\left(\mathrm{P}_{2} \mathrm{O}_{5} \mathrm{ppm}\right)$ & Kalium-tersedia $\left(\mathrm{K}_{2} \mathrm{O}\right.$ ppm $)$ \\
\hline I & $0,09 \pm 0,10$ & $157,3 \pm 71,0$ & $52,44 \pm 22,66$ \\
II & $0,12 \pm 0,02$ & $126,4 \pm 79,8$ & $41,9 \pm 30,7$ \\
III & $0,09 \pm 0,06$ & $225,7 \pm 41,6$ & $113,83 \pm 9,58$ \\
IV & 0,08 & 36 & 22,22 \\
V & $0,12 \pm 0,02$ & $39,66 \pm 5,83$ & $20,44 \pm 10,20$ \\
\hline Rata-rata & $0,10 \pm 0,08$ & $142,7 \pm 80,4$ & $52,66 \pm 31,82$
\end{tabular}

Sumber: Hasil Analisis Kelompok/ Cluster

\section{Rekomendasi Pemupukan}

Berdasar pada petunjuk saran pemupukan Nomograf yang dibuat oleh P3GI (Pawirosemadi, 1992, 1993, 1996) seperti yang disajikan di dalam Tabel 2 dan status hara tanah di dalam Tabel 8 hasil Cluster, luas dan persentase macam kombinasi rekomendasi pemupukan $\mathrm{N}, \mathrm{P}$, dan $\mathrm{K}$ pada setiap Cluster/kelompok disajikan di dalam Tabel 6.

Tabel 6. Rekomendasi Pemupukan di setiap Cluster/ Kelompok Wilayah Penelitian Unit Usaha PG. Djatiroto

\begin{tabular}{|c|c|c|c|c|c|}
\hline \multirow{2}{*}{$\begin{array}{c}\text { Kelompok } \\
\text { (Cluster) }\end{array}$} & \multicolumn{3}{|c|}{ Rekomendasi Pemupukan N-P-K (Kg/Ha) } & \multirow{2}{*}{ Luas (Ha) } & \multirow{2}{*}{$\%$} \\
\hline & $\mathrm{N}$ & $\mathrm{P}_{2} \mathrm{O}_{5}$ & $\mathrm{~K}_{2} \mathrm{O}$ & & \\
\hline I & 160 & 90 & 175 & 161,49 & 59,97 \\
\hline II & 120 & 90 & 175 & 39,79 & 14,78 \\
\hline III & 160 & 90 & 145 & 31,07 & 11,54 \\
\hline IV & 160 & 135 & 175 & 5,04 & 1,87 \\
\hline $\mathrm{V}$ & 120 & 135 & 175 & 31,89 & 11,84 \\
\hline \multicolumn{4}{|c|}{ Jumlah } & 269,28 & 100,00 \\
\hline
\end{tabular}

Memperhatikan Tabel 6, tampak bahwa sebagian besar petak kebun yang ada di wilayah penelitian memerlukan takaran pupuk nitrogen yang berat (160 kg N/ha), dengan kombinasi pupuk $\mathrm{P}$ yang ringan dan pupuk $\mathrm{K}$ yang berat, pupuk $\mathrm{P}$ yang ringan dan pupuk $\mathrm{K}$ yang sedang. Apabila dijumlah areal lahan yang memerlukan pupuk $\mathrm{N}$ dalam takaran berat adalah seluas 192,56 ha atau $71,51 \%$ dari luas total. Tingginya kebutuhan dosis pupuk $\mathrm{N}$ karena hara ini memang diambil tanaman dalam jumlah besar dan kandungan di dalam tanah rendah. Sebagian gambaran setiap ton batang tebu giling terdapat sekitar 0,92kg N (Filho, 1994).
Angka-angka pada Tabel 6, setelah pupuk N, pupuk $\mathrm{K}$ juga diperlukan dalam takaran yang cukup berat $\left(175 \mathrm{~kg} \mathrm{~K} \mathrm{~K}_{2} \mathrm{O} / \mathrm{ha}\right)$. Hal ini sesuai dengan sebaran kadar $\mathrm{K}$ tanah yang umumnya tergolong rendah dan hanya sebagian kecil di lokasi penelitian yang berkadar hara $\mathrm{K}$ sedang. Sementara itu, tebu menyerap hara $\mathrm{K}$ dalam jumlah sangat banyak, bahkan lebih banyak dari serapan hara $\mathrm{N}$ dan P. Untuk menghasilkan 100 ton batang tebu/ha tanaman menyerap $\mathrm{K}_{2} \mathrm{O}$ sebanyak 3 kuintal (Halliday, 1956). Di Fiji, hara $\mathrm{K}$ yang diserap tebu mencapai $125-220 \mathrm{~kg} \mathrm{~K} / \mathrm{ton}$ tanaman (Naidu et al., 1992). Tanaman tebu perlu dipupuk dengan pupuk $\mathrm{K}$ jika kadar K tanahnya kurang dari 148 mg/g (Filho, 1985, Ismail, 1998). 
Apabila dijumpai areal penelitian yang memerlukan pupuk $\mathrm{K}$ dalam takaran berat adalah seluas 238,21 ha atau $88,46 \%$ dari luas total.

Takaran pupuk $\mathrm{P}$ yang diberikan ringan sampai sedang. Areal penelitian yang memerlukan pupuk $\mathrm{P}$ dalam takaran ringan seluas 232,35 ha atau $86,29 \%$ dari luas total dan areal penelitian yang memerlukan pupuk $\mathrm{P}$ dalam jumlah sedang seluas 36,93 ha atau $13,71 \%$ dari luas total. Berdasarkan Tabel 9 di atas, maka dapat dibuat peta pemupukan yang disajikan pada Gambar 6 .

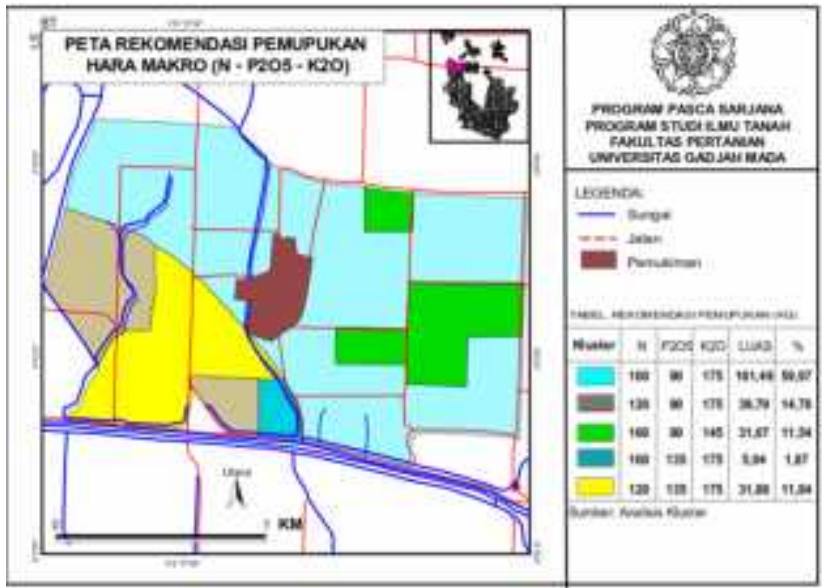

Gambar 6. Peta rekomendasi pemupukan hara makro

\section{KESIMPULAN}

Kesimpulan dari hasil penelitian ini sebagai berikut:

1. Analisis Cluster yang terbentuk 5 yaitu Kelompok I : 0,09 \pm 0,10\% N; 157,3 $\pm 71,0$ $\mathrm{mg} / \mathrm{g} \quad \mathrm{P}_{2} \mathrm{O}_{5} ; \quad 52,44 \pm 22,66 \mathrm{mg} / \mathrm{g} \quad \mathrm{K}_{2} \mathrm{O}$, Kelompok II : 0,12 $\pm 0,02 \% \mathrm{~N} ; 126,4 \pm 79,8$ $\mathrm{mg} / \mathrm{g} \mathrm{P}_{2} \mathrm{O}_{5} ; 41,9 \pm 30,7 \mathrm{mg} / \mathrm{g} \mathrm{K}_{2} \mathrm{O}$, Kelompok III : $0,09 \pm 0,06 \% \mathrm{~N} ; 225,7 \pm 41,6 \mathrm{mg} / \mathrm{g} \mathrm{P}_{2} \mathrm{O}_{5}$; $113,83 \pm 9,58 \mathrm{mg} / \mathrm{g} \mathrm{K}_{2} \mathrm{O}$, Kelompok IV : $0,08 \% \mathrm{~N} ; 36 \mathrm{mg} / \mathrm{g} \mathrm{P}_{2} \mathrm{O}_{5} ; 22,22 \mathrm{mg} / \mathrm{g} \mathrm{K} \mathrm{K}_{2} \mathrm{O}$, Kelompok V : 0,12 $\pm 0,02 \%$ N; 39,66 $\pm 5,83$ $\mathrm{mg} / \mathrm{g} \mathrm{P}_{2} \mathrm{O}_{5} ; 20,44 \pm 10,20 \mathrm{mg} / \mathrm{g} \mathrm{K}_{2} \mathrm{O}$.

2. Dalam kaitannya dengan rekomendasi pemupukan $\mathrm{N}, \mathrm{P}$, dan $\mathrm{K}$, maka hara $\mathrm{N}$ menjadi masalah utama, baru diikuti oleh hara $\mathrm{K}$, dan yang terakhir hara P. Rekomendasi pupuk di lokasi penelitian nitrogen $120-160 \mathrm{~kg} \mathrm{~N} / \mathrm{Ha}$, Fosfat $90-135 \mathrm{~kg} \mathrm{P}_{2} \mathrm{O}_{5} / \mathrm{Ha}$, dan kalium 145$175 \mathrm{~kg} \mathrm{~K} \mathrm{~K}_{2} \mathrm{O} / \mathrm{Ha}$. Satu kelompok (Cluster 3) yang terdiri dari satu petak dengan

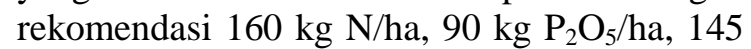
$\mathrm{kg} \mathrm{K}_{2} \mathrm{O} / \mathrm{ha}$; cluster 1 yang terdiri dari 29 petak dengan rekomendasi $160 \mathrm{~kg} \mathrm{~N} / \mathrm{ha}, 90 \mathrm{~kg}$ $\mathrm{P}_{2} \mathrm{O}_{5} / \mathrm{ha}, 175 \mathrm{~kg} \mathrm{~K} 2 \mathrm{O} / \mathrm{ha}$; cluster 2 yang terdiri dari 7 petak dengan rekomendasi $120 \mathrm{~kg} \mathrm{~N} / \mathrm{ha}$, $90 \mathrm{~kg} \mathrm{P}_{2} \mathrm{O}_{5} / \mathrm{ha}, 175 \mathrm{~kg} \mathrm{~K} 2 \mathrm{O} / \mathrm{ha}$, cluster 4 yang terdiri dari 23 petak dengan rekomendasi 160 $\mathrm{kg} \mathrm{N} / \mathrm{ha}, 135 \mathrm{~kg} \mathrm{P}_{2} \mathrm{O}_{5} / \mathrm{ha}, 175 \mathrm{~kg} \mathrm{~K} \mathrm{~K}_{2} \mathrm{O} / \mathrm{ha}$; cluster 5 yang terdiri dari 6 petak dengan rekomendasi $120 \mathrm{~kg} \mathrm{~N} / \mathrm{ha}, 135 \mathrm{~kg} \mathrm{P} \mathrm{O}_{5} / \mathrm{ha}, 175$ $\mathrm{kg} \mathrm{K}{ }_{2} \mathrm{O} / \mathrm{ha}$.

\section{DAFTAR PUSTAKA}

Bakti,.P.L.W. 2009. Analisis Kandungan Klorofil dan Laju Fotosintesis Tebu Transgenik PSIPB1 yang Ditanam di Kebun Percobaan PG. Djatiroto Jawa Timur S1 Skripsi. Fakultas Pertanian IPB. Bogor.

Balai Penelitian Tanah. 2009. Petunjuk Teknis Edisi 2, Analisis Kimia Tanah, Tanaman, Air, dan Pupuk. Balai Penelitian Tanah Deptan. Bogor.

Filho, J. O. 1994. Alternative for An Efficient Use of Mineral Fertlizer and Sugar Factory Residues with Low Soil Degradation and Environment Contamonation Risk. In Trans. 15th. World Congres of Soil Sci. Mexico, Vol 7a:395-405.

Hakim, N., M.Y Nyakpa., A.M. Lubis., S.G. Nugroho., M.A. Diha., G.B. Hong., H.H. Bailey,. 1986. Dasar-Dasar Ilmu Tanah. Penerbit Universitas Lampung. Lampung.

Herman D.Z., 2006. Kajian Potensi Tambang Dalam Pada Kawasan Hutan Lindung Di Daerah Lumajang, Jawa Timur. Proceeding Pemaparan Hasil-Hasil Kegiatan Lapangan dan Non Lapangan Tahun 2006. Pusat Sumberdaya Geologi. 
Hunsigi, G. 2001. Sugarcane in Agriculture And Industry. Kamataka Institute of Applied Agriculture Research. Sameerwadi, Bagalkot.

Ismail,I. 2008. Evaluasi Klimatik, Sebaran Hara Makro dan Rekomendasi Pemupukan di Unit Usaha Pabrik Gula Bungamayang. Peneliti pada Pusat Penelitian Perkebunan Gula Indonesia. Pasuruan.

Naidu, L. G. K. 1992. Land Suitability Evaluation of Major Sugarcane Growing Soils of Karnataka. Ph.D. Thesis. Univ. Agric. Sciences, GKVK, Bangalore.
Puslit Sukosari. 2014. Data Produktifitas Tahunan 2013. PTPN XI (Persero). Lumajang. Pawirosemadi, M. 1996. Nomograf Analisis Tanah dan Daun : Piranti untuk Penetapan

Takaran Pupuk dan Evaluasi Pengelolaan Budidaya Tanaman Tebu. In MPG XXVIII (3-4):1-8. P3GI, Pasuruan.

Pawirosemadi, M. 2011. Budidaya Tanaman Tebu. Universitas Negeri Malang. Malang

Sanchez, P.A., 1992. Sifat dan Pengelolaan Tanah Tropika.PenerbitITB.Bandung. 